UDC 341.63:339.5

DOI:10.5937/RKSPP1901131P

JELENA S. PEROVIĆ VUJAČIĆ

\title{
OBLIGATIONS OF ARBITRATORS IN INTERNATIONAL COMMERCIAL ARBITRATION
}

This paper seeks to address the obligations of arbitrators in international commercial arbitration. By way of introduction, it examines the legal relationship between the arbitrators and the parties governed by the contract they conclude. The central part of the analysis is devoted to the duties assumed by an arbitrator by accepting his appointment, focusing on a) principal duties of independence and impartiality and observing the fundamental principles of arbitration and $b$ ) other major obligations owed by an arbitrator, namely the duties of care, efficiency and expediency, adjudicating the dispute, the duty to disclose potential conflicts of interests and the duty of confidentiality. This is followed by an examination of possible legal consequences of breaches of arbitrators' obligations: setting aside of the award, termination of arbitrators' functions and arbitrators' civil liability. These issues are addressed in the light of the relevant solutions of uniform rules, national laws governing arbitration, rules of the leading arbitration institutions, as well as the views prevailing in the doctrine and international court and arbitration practice.

Key words: arbitrator, obligation, arbitration, arbitration agreement, arbitral procedure

\section{INTRODUCTORY REMARKS}

By accepting his appointment, an arbitrator undertakes the obligations required for a successful conduct and resolution of arbitration proceedings. Their

Prof. Dr. Jelena S. Perović Vujačić, President of the Kopaonik School of Natural Law - Slobodan Perović, full professor, Faculty of Economics, University of Belgrade, e-mail: jperovic@beotel.rs 
common denominator is the requirement for an arbitrator to conduct the proceedings with due care and efficiently and to resolve the case under the final award. All arbitrator's obligations stem from the necessity to fulfil that requirement. Strict observance of arbitrator's obligations, from the moment of accepting the appointment until the dispute is resolved, is crucial for the course, and sometimes even the outcome of the arbitration proceedings. A breach of these obligations may result in setting aside of the award and may trigger the issue of arbitrator's civil liability.

A comprehensive understanding of arbitrators' obligations in international commercial arbitration requires an analysis of the legal relationship between the arbitrators and the parties, specific and individual obligations owed by arbitrators and the legal consequences of breaches of such obligations.

\section{THE LEGAL RELATIONSHIP BETWEEN THE ARBITRATORS AND THE PARTIES}

Receptum arbitrii. - The legal relationship between the arbitrators and the parties is governed by a contract they enter into. ${ }^{1}$ It is based on this contract that the arbitrators acquire the rights and undertake the obligations relevant to the arbitration proceedings. In the arbitration law theory, such contract between the arbitrators and the parties is commonly called receptum arbitrii. ${ }^{2}$

1 The prevailing position in the arbitration law is that the legal relationship between an arbitrator and the parties is of contractual nature. See Emmanuel Gaillard, John Savage (editors), Fouchard Gaillard Goldman On International Commercial Arbitration, Kluwer Law International, The Hague, 1999, p. 599 stating "There is no longer any serious dispute as to the existence of a contract between the arbitrators and the parties. The Swiss law (doctrines and judgments of the Swiss Federal Court) embraces the stand that the legal relationship between the arbitrators and the parties is based in the contract (see for example Gabrielle Kaufmann-Kohler, Antonio Rigozzi, Arbitrage international: Droit et practique à la lumière de la LDIP, 2nd ed. 2010, nr. 24; Pierre Lalive, Jean François Poudret, Claude Reymond, Le droit de larbitrage interne et international en Suisse, Lausanne, 1989, Art 179, N 6-8; Jean François Poudret, Sébastien Besson, Comparative Law of International Arbitration, $2^{\text {nd }}$ edition, London, 2007, p. $367 \mathrm{ff}$ ), and the same view prevails in the doctrine and jurisprudence of most other countries of the continental legal tradition (comparative law study, Nigel Blackaby and Constantine Partasides with Alan Redfern and Martin Hunter, Redfern and Hunter on International Arbitration, Fifth edition, Student Version, Oxford University Press, 2009, p. 329 ff). In recent national literature, see for example Gašo Knežević, Vladimir Pavić, Arbitraža i $A D R$, Beograd, 2010, pp. 87-88; Maja Stanivuković, Međunarodna arbitraža, Beograd, 2013, p. 181; Jelena Perović, Ugovor o međunarodnoj trgovinskoj arbitraži, Beograd, 2002, pp. 186-191.

2 On terminology, René David, Larbitrage dans le commerce international, Economica, Paris, 1982, p. 371; Thomas Clay, Larbitre, Dalloz, 2001, pp. 487-489; Mathieu de Boisséson, Le droit français de l'arbitrage interne et international, GLN Joly, 1990, p. 175 and p. 575. 
The contract between the arbitrators and the parties has seldom been the subject of a systematic scrutiny by legal doctrine. ${ }^{3}$ The attention was mostly drawn to the issue of its legal nature, ${ }^{4}$ generating different views on the subject - from agency agreement, to an independent contractor agreement, to an agreement for the provision of services. ${ }^{5}$ The prevalent position on this issue, that this is a suigeneris agreement, arises from the hybrid nature of arbitration - contractual by its source and judicial by its object, and from the specific legal relationship existing between the arbitrators and the parties. ${ }^{6}$

Receptum arbitrii is concluded by an arbitrator (where the dispute is decided by a sole arbitrator) or arbitrators (where the dispute is referred to the arbitral tribunal) and the parties to the dispute. It is argued in legal doctrine that an arbitrator has relationship with both parties to the dispute, regardless of being nominated by only one of the parties. ${ }^{7}$ It bears no significance whatsoever whether the arbitrators were nominated directly by the parties to the dispute or a third party arbitration institution, nomination body or the competent court. ${ }^{8}$

The contract between the arbitrators and the parties to the dispute is a bilateral contract, as it generates mutual obligations for the contractual parties. ${ }^{9}$

3 See more in J. Perović, Ugovor o međunarodnoj trgovinskoj arbitraži, op. cit., p. 190 ff.

4 Another issue under debate is whether or not it is a procedural law or a material law contract. The contemporary doctrine and case law take the view that receptum arbitrii is a material law contract (see Bernhard Berger, Franz Kellerhals, International and Domestic Arbitration in Switzerland, Third edition, Berne, 2015, p. 342; E. Gaillard, J. Savage (editors), Fouchard Gaillard Goldman On International Commercial Arbitration, op. cit., p. $604 \mathrm{ff}$.

5 On legal nature of receptum arbitrii: E. Gaillard, J. Savage (editors), Fouchard Gaillard Goldman On International Commercial Arbitration, op. cit., pp. 605-608; R. David, op. cit., pp. 371-372; P. Lalive, J.F. Poudret, C. Reymond, op. cit., p. 332; Christian Gavalda, Lucas de Leyssac, L'arbitrage, Dalloz, Paris, 1993, p. 43; Pierre Jolidon, Commentaire du Concordat suisse sur l'arbitrage, Berne, 1984, p. 231; Charles Jarrosson, La notion d'arbitrage, LGDJ, Paris, 1987, p. $302 \mathrm{ff}$.

6 E. Gaillard, J. Savage (editors), Fouchard Gaillard Goldman On International Commercial Arbitration, op. cit., p. 607.

7 See B. Berger, F. Kellerhals, op. cit., p. 343; Julian D.M. Lew, Loukas Mistelis, Stefan Kröll, Comparative International Commercial Arbitration, Kluwer Law International, the Hague, 2003, p. 277. The theory considers the question whether receptum arbitrii is a special contract or a "tripartite" contract of arbitration (see Murray L. Smith, "Contractual Obligations Owed by and to Arbitrators: Model Terms of Appointment”, Arbitration International, Vol. 8, no. 1, LCIA, 1992, p. 18 ff).

8 G. Knežević, V. Pavić, op. cit., p. 88.

9 On bilateral contracts in general, Slobodan Perović, Obligaciono pravo, Beograd, 1990, pp. 197-203. 
Furthermore, it is an unnamed contract (contrat inommé) ${ }^{10}$ and a contract of successive performance. ${ }^{11}$ Such contract is concluded intuitu personae given that the choice of arbitrators is made based on their personal abilities, qualifications, experience, reputation etc. It follows that an arbitrator must personally meet his obligations and may not transfer such obligations to the third parties. ${ }^{12}$ The performance of the obligations under this contract is carried out in full in the course of the arbitration proceedings, and arbitrator's authorities must be within the boundaries defined and allowed by the applicable arbitration law. ${ }^{13}$ Receptum arbitrii as a rule expires with the issue of the final award by the arbitrators. Exceptionally, it may come to an end before the final award is made due to withdrawal of the parties from arbitration or some reason pertaining to the arbitrator himself (e.g. challenge, resignation, removal). ${ }^{14}$

The existence of receptum arbitrii is explicitly accepted in the jurisprudence of a number of countries. Thus, the Swiss Supreme Court recognises that the legal relationship between the arbitrators and the parties is contractual in character, ${ }^{15}$ and has particularly examined the legal effects of receptum arbitrii in some of its judgments. ${ }^{16}$ In England, for example, the courts have confirmed that, by accepting their appointment, arbitrators contractually undertake to fulfil their brief diligently, in return for remuneration ${ }^{17}$. The French courts have developed similar jurisprudence. ${ }^{18}$ On the other hand, national laws as a rule do not provide special provisions to govern such contracts. The Serbian Arbitration Law contains only

10 Not provided under the law in Serbian or other legal systems (based on the sources available to the author). On unnamed contracts in general, S. Perović, op. cit., pp. 192-194.

11 On contracts of successive performance in general, S. Perović, op. cit., pp. 211-213.

12 On intuitu personae contracts in general, S. Perović, op. cit., pp. 232-233.

13 N. Blackaby and C. Partasides with A. Redfern and M. Hunter, op. cit., p. 315.

14 For details, E. Gaillard, J. Savage (editors), Fouchard Gaillard Goldman On International Commercial Arbitration, op. cit., p. 602.

15 See B. Berger, F. Kellerhals, op. cit., pp. 342-343 and relevant references underneath the text.

16 See for example Judgments 4A_391/2010 and 4A_399/2010 of 10 November 2010 (subsequently joined) where receptum arbitrii was examined in the context of arbitrators' fees and Judgment 4A_490/2013 of 28 January 2014 relating to the deadline for issuing the award.

17 K/S Norjarl A/S v. Hyundai Heavy Industries Co. Ltd, (1992) I Q.B. 863; (1991) 3 All E.R. 211; (1991) 3 W.L.R. 1025; (1991) I Lloyd's Rep. 524 (C.A. 1990). Cit. from E. Gaillard, J. Savage (editors), Fouchard Gaillard Goldman On International Commercial Arbitration, op. cit., p. 601.

18 Compagnie Europeene de Cereals SA v. Tradax Export S.A, (1986) 2 Lloyd's Rep. 301 (Hight Ct., Q.B. Com. Ct. 1986). Cit. from E. Gaillard, J. Savage (editors), Fouchard Gaillard Goldman On International Commercial Arbitration, op. cit., p. 601. 
a provision enjoining arbitrators to make a written statement about accepting their duties (Art 20).

"Status approach". - The common view in international arbitration law is that the legal relationship between the arbitrators and the parties rests on a contractual basis. Still, some authors place a strong emphasis on arbitrator's judicial powers deriving from the law; an arbitrator is authorised to adjudicate the dispute, which gives him a status comparable to that of a judge, while the rights and the obligations undertaken by the arbitrator fall within the domain of the public interest (so-called "status approach"19). ${ }^{20}$ They take the position that the legal relationship between the arbitrators and the parties is based directly in the law as source of arbitrators' authority, regardless of whether or not there is an agreement of private law entered by and between them. ${ }^{21}$

This view is not unjustified, as the arbitrator, similar to any judge in a court of law, is authorised to adjudicate the dispute. ${ }^{22}$ Still, unlike the judge, who is obli-

19 G. Knežević, V. Pavić, op. cit., p. 88.

20 Exponents of this "status approach" commonly referred to in literature are Mustill and Boyd (Michael J. Mustill, Stewart C. Boyd, Commercial Arbitration, $2^{\text {nd }}$ edition, London and Edinburgh, Butterwords, 1989, p. $220 \mathrm{ff})$. For more details on this approach and its comparison to the contract theory from the viewpoint of the English law, see M.L. Smith, op. cit. (pp. 17-39), who inclines towards the contractual character of the legal relationship between the arbitrators and the parties, while declaring that addressing all issues raised by "status" and contract theory would be "a labour of Sisyphus" (p. $34 \mathrm{ff}$ ). Speaking of literature from the domain of the continental legal tradition, commonly quoted advocates of the "status approach" are Berger and Kellerhals who sharply criticise the contract theory and insist that the relationship between the arbitrators and the parties cannot be deemed based on contractual arrangements between them, but instead on a statutory legal relationship. In details, B. Berger, F. Kellerhals, op. cit., pp. 343-344.

21 B. Berger, F. Kellerhals, ibidem.

22 These judicial powers vested in arbitrators draw a major distinction between the arbitrators and the agents of the parties to a dispute. In that respect, the European Court of Justice found that the principal and habitual obligation of the arbitrators involves settling a dispute between two or more parties, and therefore the role of an arbitrator is different from that of an agent (Court of Justice of the European Communities, 16 September 1997, Case C-145/96, Bernd von Hoffmann see Finanzamt Trier, 1997 E.C.R. I-4857, available at: http://curia.europa.eu/juris/). At the same time, these powers are one of the key points of difference between the arbitration and some other similar methods of alternative dispute resolution. On alternative dispute resolution, see. G. Knežević, D. Pavić, op. cit., pp. 183-255, drawing a distinction between the arbitration and (other) methods of alternative dispute resolution, and pointing out that "the arbitral award, similar to a court judgment, is binding on the parties, i.e. produces effects of finality and enforceability, whereas other ADR methods end with agreements producing effects in terms of the law of obligations" (p. 188). However, although he adjudicates a dispute, an arbitrator may not be equated with a local judge. In detail, E. 
gated to settle the case referred to him, the arbitrator, akin to a "private judge", is at a liberty in each given case to accept or turn down his appointment. While the powers of a judge derive directly from the law, the powers of the arbitrator stem above all from the concurrent wills of the parties that entrusted him with the case, and are accepted by the arbitrator as he enters into receptum arbitrii. By accepting the mission entrusted to him, the selected arbitrator must endeavour to justify the trust placed in him by the parties. It is exactly that trust, which is essentially a personal touch in the relationship between the arbitrator and the parties, that makes the fundamental difference with the judge in any national judiciary system. ${ }^{23}$

Three legal relationships. - Where the arbitration agreement ${ }^{24}$ provides that the dispute (or disputes) shall be settled in accordance with the rules of a certain arbitration institution, the doctrine recognises three legal relationships: the contract between the parties and the selected arbitration institution, the contract between the arbitration institution and the arbitrators, and the contract between the arbitrators and the parties (receptum arbitrii). ${ }^{25}$

In the first place, the parties to the arbitration agreement enter into a contract with the selected arbitration institution. By setting and releasing the arbitration rules, the arbitration institution sends a general and standing offer (to an unidentified number of persons that may appear as parties to a dispute), ${ }^{26}$ and the parties to the arbitration agreement identifying specific arbitration institution, essentially accede to the offer thus made. ${ }^{27}$ The performance of the contract between the parties and the arbitration institution commences at the time of initiating proceedings before the selected arbitration institution "administering" the

Gaillard, J. Savage (editors), Fouchard Gaillard Goldman On International Commercial Arbitration, op. cit., p. $560 \mathrm{ff}$.

23 J. Perović, Međunarodna trgovinska arbitraža, op. cit., p. 173 ff.

24 On arbitration agreement in general, J. Perović, Međunarodna trgovinska arbitraža, op. cit.; Jelena Perović, Standardne klauzule u međunarodnim privrednim ugovorima, Beograd, 2012, pp. 187-229.

25 E. Gaillard, J. Savage (editors), Fouchard Gaillard Goldman On International Commercial Arbitration, op. cit., pp. 602-604.

26 This is a contract which, after the manner it is entered into, falls within the group of adhesion contracts, although the parties are able, up to a point, to depart from certain provisions of the rules or enter specific provisions they have agreed upon. On adhesion contracts in general, $\mathrm{S}$. Perović, op. cit., pp. 217-225.

27 See E. Gaillard, J. Savage (editors), Fouchard Gaillard Goldman On International Commercial Arbitration, op. cit., p. 602. 
proceedings, i.e. performing organisational and technical tasks relevant to the initiated dispute. ${ }^{28}$

Furthermore, a separate contract is concluded between the arbitration institution on the one hand and each arbitrator on the other. Based on this contract, the arbitration institution undertakes to treat the nominated person as the arbitrator within its organisational and administrative competencies, and to pay to him the remuneration and cover his costs in accordance with its rules, while the arbitrator undertakes to carry out the assumed duties under the arbitration institution's aegis and in compliance with its rules. ${ }^{29}$

The conclusion of the above contracts does not significantly affect the legal relationship between the arbitrators and the parties However, the involvement of the arbitration institution as such affects the manner of exercising rights and duties arising from receptum arbitrii. ${ }^{30}$

\section{DUTIES OF AN ARBITRATOR}

Legal theory lists numerous duties owed by arbitrators grouped and classified around different criteria. ${ }^{31}$ Without going into details of such classifications, we shall proceed to examine the principal duties of arbitrators and subsequently consider other arbitrators' duties that feature prominently, particularly in view of the legal consequences of their non-fulfilment.

28 The arbitration institution itself does not resolve disputes, it merely "administers" and organises dispute resolution by arbitrators in accordance with its rules. See for example Art 1(2) Rules of the International Court of Arbitration of the International Chamber of Commerce (hereinafter: Rules and ICC Court of Arbitration) which explicitly states that the ICC International Court of Arbitration does not itself resolve disputes, but rather administers the resolution of disputes by arbitrators. For details of the competencies, organisation and activities of the ICC International Court of Arbitration and its Secretariat, Jason Fry, Simon Greenberg, Francesca Mazza, The Secretariat's Guide to ICC Arbitration, International Chamber of Commerce ICC, Paris, 2012, p. 13-27. Herman Verbist, Erik Schäfer, Christophe Imhoos, ICC Arbitration in Practice, Second Revised Edition, Kluwer Law International, The Netherlands, 2016, p. 13-23.

29 E. Gaillard, J. Savage (editors), Fouchard Gaillard Goldman On International Commercial Arbitration, op. cit., p. 604.

30 Ibidem.

31 See. for example N. Blackaby and C. Partasides with A. Redfern and M. Hunter, op. cit., pp. 326-341, grouping the duties of an arbitrator around three categories - duties imposed by the parties, duties imposed the by law, and ethical duties. Other classifications, for example in E. Gaillard, J. Savage (editors), Fouchard Gaillard Goldman On International Commercial Arbitration, op. cit., pp. 609-613; J.D.M. Lew, L. Mistelis, S. Kröll, op. cit., p. 279 ff; Toni Deskoski, Megunarodno arbitražno pravo, Skopje, 2016, pp. 212-214. 


\section{Principal duties}

An arbitrator must be impartial and independent of the parties and the subject of dispute, ${ }^{32}$ must treat the parties equally and give each party a full opportunity to present arguments and evidence in support of its case, and to respond to the actions and submissions of the other party. ${ }^{33}$ These are the principal duties of an arbitrator which stem from his judicial powers and are universally accepted in the international conventions relevant to arbitration, the UNCITRAL Model Law on International Commercial Arbitration ${ }^{34}$ (hereinafter: UNCITRAL Model Law), ${ }^{35}$ national laws governing arbitration, particularly those modelled after the UNCITRAL Model Law, ${ }^{36}$ the UNCITRAL Rules of Arbitration ${ }^{37}$ (hereinafter: UNCITRAL Rules), ${ }^{38}$ as well as the rules of all reputable arbitrations institutions. It is in the light of these principal duties of an arbitrator that we should view his other duties in arbitral proceedings.

\section{Due care, efficiency in conducting proceedings, observing the time limit for making the award}

Due care in general. - In performing his functions, an arbitrator must act with the due care required for a successful conduct and completion of the arbitration proceedings. ${ }^{39} \mathrm{He}$ is required to devote the necessary time to the arbitration dispute he was appointed to, as well as to apply the knowledge, expertise and

32 For more details on the requirement for independence and impartiality of an arbitrator, Jelena Perović, "Sumnja u nezavisnost ili nepristrasnost arbitra kao osnov zahteva za njegovo izuzeće”, Pravni život No. 11/2017, Beograd, 2017, pp. 63-78; Davor Babić, "Nezavisnost i nepristrasnost arbitara", Pravo u gospodarstvu (PUG), 3/2008, Zagreb, p. 672).

33 A breach of these fundamental principles constitutes grounds for setting aside the arbitral award and for refusing its recognition and enforcement. See the Serbian Arbitration Law (Arts 58 and 66) and the Convention on the Recognition and Enforcement of Foreign Arbitral Awards of 10 June 1958 (hereinafter: New York Convention), Art V.

34 From 1985 as revised in 2006.

35 Art 12.2.

36 See the Serbian Arbitration Law (Art 19 Para 3 and Art 33).

37 From 1976 as revised in 2010.

38 Art 12.1.

39 In more detail, B. Berger, F. Kellerhals, op. cit., p. 345; E. Gaillard, J. Savage (editors), Fouchard Gaillard Goldman On International Commercial Arbitration, op. cit., p. 1130; N. Blackaby and C. Partasides with A. Redfern and M. Hunter, pp. 327-334. 
skills necessary in the particular case for the analysis and resolution of disputable issues. An arbitrator is required to conduct the proceedings efficiently ${ }^{40}$ and to observe the procedural deadlines, and in particularly the deadline set for rendering the award. It is an obligation universally acknowledged in the law of arbitration, although often not explicitly provided in the sources of the arbitration law. ${ }^{41}$ The Serbian Arbitration Law provides for this obligation in general terms, enjoining the arbitrator to perform his functions "diligently and efficiently".

Sometimes an arbitrator is unable to meet these requirements for different reasons, for example due to the lack of (or insufficient) knowledge of the applicable law, ${ }^{42}$ or lack of familiarity with the language of the arbitration ${ }^{43}$ or because he may not have the necessary time available to devote his attention to the dispute. In such cases, he is expected to decline the appointment. ${ }^{44}$ On the other hand, if an appointed arbitrator fails to perform his functions with due care, he may be challenged ${ }^{45}$ in accordance with the agreement of the parties or, in the absence of such an agreement, by the arbitration institution ${ }^{46}$ or the competent court, upon request of a party to the dispute. ${ }^{47}$

40 Widespread in international arbitration practice are certain requirements and recommendations as to the duties of arbitrators to conduct the arbitration in an expeditious and cost-effective manner, i.e. to control the time and costs of the arbitration. Hence for example, the ICC Rules provide for three steps in organising the arbitration: drawing up Terms of Reference (Art 23), convening a case management conference (Art 24.1) and establishing procedural timetable (Art 24.2). More details, Jelena Perović, "Efikasnost arbitražnog postupka”, Pravo i privreda, No. 4-6/2017, pp. 461-469.

41 In details, see E. Gaillard, J. Savage (editors), Fouchard Gaillard Goldman On International Commercial Arbitration, Ibidem; for the English law see M.L. Smith, op. cit., p. 28.

42 See Jelena Perović, "Konstituisanje arbitražnog veća u međunarodnoj trgovinskoj arbitraži”, Pravni život No. 11/2016, Belgrade, 2016, pp. 230-231.

43 See Jelena Perović, "Jezik arbitražnog postupka u međunarodnoj trgovinskoj arbitraži" Liber amicorum Gašo Knežević, Pravni fakultet Univerziteta u Beogradu, Centar za izdavaštvo i informisanje, Udruženje za arbitražno pravo, Beograd, 2016, pp. 274-290

44 B. Berger, F. Kellerhals, Ibidem.

45 This is a broadly accepted rule, contained in national laws and rules of arbitration institutions. See The UNCITRAL Model Law, Art 14 (1). For the Serbian law, see the Arbitration Law (Art 25).

46 Under the ICC Rules, an arbitrator may be replaced even upon initiative of the arbitral tribunal itself - Art 15 (2).

47 In this regard, attention should be given to the opinion of Berger and Kellerhals that the right to challenge should not be reserved to the parties to the dispute but should also be available to other members of the arbitral tribunal (B. Berger, F. Kellerhals, op. cit., p. 345). 
The ICC Rules - statement of acceptance, availability, impartiality and independence. - Under the ICC Rules ${ }^{48}$, a prospective arbitrator must sign a statement of acceptance, availability, impartiality and independence before appointment or confirmation. ${ }^{49}$ Speaking of availability, it is highlighted in the comments to the Rules that arbitrators are sometimes unable to make an objective prediction of their time schedule, and accept appointments in spite of a huge case load preventing their necessary commitment to the specific case. As a rule this results in extending deadlines in arbitration proceedings, and in particular the deadlines for rendering the award, which in the practice of the Court sometimes led to the withdrawal of the arbitrator or his replacement by the Court. ${ }^{50}$ With the aim of arriving at the fairest possible estimate of an arbitrator's availability, the potential arbitrator is also required to indicate in the above statement the number of arbitrations he is currently involved in as arbitrator or counsel, as well as the number of currently pending court litigations. It is argued in the Comments to the ICC Rules that this statement achieves a twofold effect. On the one hand, the Court and the parties to the dispute are informed in advance of the arbitrator's availability (based on which the parties may lodge a complaint, and the Court may decide not to confirm the arbitrator's appointment), ${ }^{51}$ while, on the other hand, the arbitrator himself is encouraged to timely consider the issue of the time he can devote to the particular arbitration, particularly in view of the requirement for conducting the proceedings efficiently. ${ }^{52}$

Time limit for rendering an award. - The time limit for rendering the award is set in order to ensure the most efficient possible resolution of the arbitration dispute. The parties may define such deadline directly in the arbitration agreement or indirectly, by agreeing on the rules of a particular arbitration institution, or the choice of law or the rules governing the arbitration.

48 The latest revision of the Rules is dated 1 March 2017.

49 Art 11(2).

50 J. Fry, S. Greenberg, F. Mazza, The Secretariat's Guide to ICC Arbitration, op. cit., p. 120 ff; H. Verbist, E. Schäfer, Ch. Imhoos, op. cit., p. 66.

51 According to the data available to the Secretariat of the Court, between 2009 and 2011, the Court decided not to confirm the appointment of three arbitrators based on the information on their availability contained in the above statement (in one of those statements, the arbitrator indicated that he was involved in 68 and 83 arbitrations as tribunal chair and co-arbitrator respectively). In details, J. Fry, S. Greenberg, F. Mazza, The Secretariat's Guide to ICC Arbitration, op. cit., p. 121.

52 J. Fry, S. Greenberg, F. Mazza, The Secretariat's Guide to ICC Arbitration, op. cit., p. 120; H. Verbist, E. Schäfer, Ch. Imhoos, ibidem. 
Time limit fixed under the arbitration agreement. - When the deadline for making an award is set in the arbitration agreement itself, the arbitrators are sometimes unable to meet this obligation for objective reasons. Specifically, at the time of entering into an arbitration agreement, the parties are hardly able to gauge all the circumstances relevant to the course of the arbitration and arrive at a precise deadline for making the award. This is particularly true in case of an arbitration clause agreed upon at the time when the dispute has not yet arisen, and it was uncertain if any disputes would arise at all. In the arbitration practice, the uncertainty as to the time limit for rendering the award so fixed may arise for different reasons, given that the length of the proceedings depends above all on the complexity of the case and other relevant circumstances which vary from case to case. ${ }^{53}$ The major problem in that regard concerns the time required to constitute the arbitral tribunal, particularly in ad hoc arbitration, where collaboration with the competent state courts at the seat of the arbitration is of greatest importance. For these and other justified reasons (for example the need to collect evidence), the deadline for rendering the award fixed in the arbitration agreement may as a rule be extended based on explicit or implicit agreement of the parties to the dispute. $^{54}$

Time limit fixed in the rules of arbitration institutions. - The rules of arbitration institutions may be divided between those that set the time limit for rendering the award and those that keep silent on this point. The rules providing for a time limit vary significantly, both in terms of the time allowed and the moment in the arbitration from which such time limit starts to run. Thus for example, under the ICC Rules, the time limit for rendering the final award is six months from the date of signing the so-called Terms of Reference, however the Court may fix a different time limit based on the procedural timetable. ${ }^{55}$ The Court may extend the time limit pursuant to a "reasoned request" from the arbitrators or on its own initiative should it deem necessary to do so. ${ }^{56}$ Under the Stockholm Rules ${ }^{57}$ the final award must be made no later than six months from the date the case was

53 In details, N. Blackaby and C. Partasides with A. Redfern and M. Hunter, op. cit., pp. 557-559.

54 See N. Blackaby and C. Partasides with A. Redfern and M. Hunter, ibidem; B. Berger, F. Kellerhals, op. cit., p. 338; E. Gaillard, J. Savage (editors), Fouchard Gaillard Goldman On International Commercial Arbitration, op. cit., pp. 757-759.

55 Art $31(1)$.

56 Art $31(2)$.

57 Arbitration Rules of the Arbitration Institute of the Stockholm Chamber of Commerce SCC Rules (1 January 2017). 
referred to the arbitral tribunal, ${ }^{58}$ under the Milan Rules ${ }^{59}$ the final award must be filed within six months from the constitution of the arbitral tribunal, unless otherwise agreed in the arbitration agreement, ${ }^{60}$ and under the DIS Rules ${ }^{61}$ arbitrators must send the final award to the DIS for review in principle within three months after the last hearing or the last authorised submission, whichever the later. ${ }^{62}$ All of the above rules allow for extension of the time limit for rendering the award. On the other hand, the Swiss Rules of International Arbitration (hereinafter: Swiss Rules) ${ }^{63}$ and the LCIA Rules ${ }^{64}$ do not provide for the deadline for making the award. The Rules of the Permanent Arbitration at the Chamber of Commerce and Industry of Serbia (SA Rules) do not contain special provisions as to the time limits for issuing the award, but rather provide in general terms that the arbitration proceedings, as a rule, must be completed within six months from the date of appointment of the arbitral tribunal or the sole arbitrator. As an exception to this rule, the arbitral tribunal or the sole arbitrator may decide, upon obtaining prior consent of the SA President, to extend the arbitral proceedings if so required in order to obtain evidence, or if the parties request so, or for other justified reasons. ${ }^{65}$

National laws. - The national laws governing arbitration as a rule do not provide explicitly for the deadline for making the award and the legal consequences of missing such deadline. ${ }^{66}$ As an exemption, the Italian Code of Civil Procedure prescribes that, unless the parties have agreed otherwise, the arbitrators must render the award within 180 days upon acceptance of their appointment, and where the arbitrators did not all accept appointment at the same time, the

58 Art 43.

59 Arbitration Rules of the Milan Chamber of Arbitration - CAM Rules (1 March 2019).

60 Art 36.

61 Arbitration Rules of the German Arbitration Institute - DIS Arbitration Rules (1 March 2018) .

62 Art 37 further provides that the Arbitration Council may reduce the fee of one or more arbitrators based upon the time taken by them to issue the award, upon consultation with the arbitrators and considering the circumstances of the case.

63 Swiss Rules of International Arbitration - Swiss Rules (1 June 2012).

64 Arbitration Rules of the London Court of International Arbitration - LCIA Arbitration Rules (1 October 2014).

65 Art 38 of the Rules. A similar provision is contained in the Rules of the Belgrade Arbitration Centre - BAC Rules (Art 32).

66 Comparative law study, N. Blackaby and C. Partasides with A. Redfern and M. Hunter, op. cit., p. 557. 
time limit starts to run from the day of the last acceptance (Art 820, Para 1). ${ }^{67}$ The Code identifies missing the deadline for rendering the award as one of the grounds for setting it aside (Art 829 Para 6). The Code explicitly provides that the arbitrators are required to render the award within the time limit fixed by the parties or by the law, and if they fail to do so and the award is set aside on such grounds, they shall be held liable for damages (Art 813 Para 2). Under the French New Civil Procedure Code, if no time limit is fixed in the arbitration agreement for making the award, the duration of arbitrators' mandate is six months from the day the last arbitrator accepted his mandate. ${ }^{68}$ However, this rule in France is not applicable to international arbitration, unless the parties have agreed to apply the French law to arbitration. ${ }^{69}$ In the US law, the deadline for rendering the award varies from state to state (often 30 days from declaring the hearings closed), but may be extended subject to an agreement of the parties or by the court. ${ }^{70}$ The Serbian Arbitration Law does not provide for the time limit for rendering the award.

Legal consequences of "late" awards. - Legal consequences of the breaches of the duty to render the award within the prescribed time limit may include arbitrator's civil liability and setting aside the award and they depend on the relevant rules of the applicable law. ${ }^{71}$ Arbitrators' civil liability will be discussed in the section on legal consequences of the breaches of arbitrators' duties, and here we will focus on the possibility of setting aside the award over missed deadline for issuing the award.

Different approaches have been adopted in the comparative law as to the setting aside of the award rendered upon expiry of the appropriate time limit. Thus, for example, the Italian Code of Civil Procedure, as mentioned above, specifies missing the deadline for rendering the award as one of the grounds for setting it aside (Art 829 Para 6). Furthermore, under the French law, an award made after the expiration of the fixed deadline may be set aside on the gro-

67 See Arts 820 and 821 of the Code in entirety.

68 Art 1456.

69 E. Gaillard, J. Savage (editors), Fouchard Gaillard Goldman On International Commercial Arbitration, op. cit., p. 755.

70 N. Blackaby and C. Partasides with A. Redfern and M. Hunter, ibidem.

71 Comparative law study, E. Gaillard, J. Savage (editors), Fouchard Gaillard Goldman On International Commercial Arbitration, op. cit. p. 613 ff. For the English law, see M. J. Mustill, S. C. Boyd, op. cit. p. $231 \mathrm{ff}$; Russell on the Law of Arbitration, Walton and Vitoria Eds., $20^{\text {th }}$ ed., Stevens and Sons, 1982, p. 121, stating that the arbitrator may be held liable for breach of contract should he fail to render the award within reasonable time. 
unds that it was made on the basis of an expired arbitration agreement. ${ }^{72}$ Specifically, Art 1502 of the New Code of Civil Procedure lists among the grounds for setting aside the award the absence, nullity, or expiry of the arbitration agreement. If the arbitrators have rendered the award based on an expired arbitration agreement, the arbitrators no longer had the powers to render an award. Although under the compétence-compétence principle, the arbitrators have the power to decide themselves about their own competence, their decision on their own competence may be subject to judicial control if the procedure for setting aside the award has been set in motion. In that regard, if the parties have provided for a time limit for issuing the award (whether directly in the arbitration agreement or indirectly - by agreeing on the rules of a particular arbitration institution, or the choice of law or the rules governing arbitration), such time limit must be observed, and if missed, the award may be set aside. An award made abroad under the same circumstances could be refused recognition and enforcement in France on the same grounds. ${ }^{73}$ A similar, albeit somewhat broader view is taken by the Swiss Code on International Private Law, which provides that the award may be challenged if the arbitral tribunal erroneously held that it had or did not have jurisdiction. ${ }^{74}$ On the other hand, when it comes to the comparative law in general, the doctrine states that the courts of many countries are against setting aside the "late" award, particularly where the court is not authorised to extend the time limit for rendering the award on the initiative of one party alone, but only based on the mutual agreement of the parties. Thus, for example, the US courts have shown remarkable restraint as to setting aside an award issued upon expiry of the relevant deadline. ${ }^{75}$

View held by the Federal Supreme Court of Switzerland. - The Swiss Federal Supreme Court took a stand on this issue in a case of setting aside the award where the Appellant argued that the Sole Arbitrator rendered the award after he had resigned.

In this case, the arbitration proceedings began on 7 June 2010, and the hearing was closed on 4 May 2011. The Counsel for the Respondent received the award on 3 September 2013, and the Appellant's counsel received it on 4 September 2013. Delivery of the award was preceded by an exchange between the coun-

72 See E. Gaillard, J. Savage (editors), Fouchard Gaillard Goldman On International Commercial Arbitration, op. cit. p. 759.

73 Art 1502 Para 1 of the French New Code of Civil Procedure. V. E. Gaillard, J. Savage (editors), Fouchard Gaillard Goldman On International Commercial Arbitration, op. cit., p. 759.

74 Art 190.2 (b).

75 See N. Blackaby and C. Partasides with A. Redfern and M. Hunter, op. cit., p. 557. 
sels of the parties and the Arbitrator, with counsels of the parties inquiring about 10 times as to the status of the work on the award and demanding the date of the award to be made. At one point, the Arbitrator set the date for issuing the award at 31 May 2013. As the award was not delivered on that date, the parties demanded from the Arbitrator to resign from his functions if he should fail to deliver within one week, and the Arbitrator's reaction was to propose to resign if the award was not rendered by 30 June 2013. As the award was not delivered even by that date, the counsels of the parties extended the deadline to 2 September 2013 issuing the following ultimatum: "your resignation will be accepted and effective as of 2 September 2013 at 5:00 p.m. should no award have been issued and received in the meantime", and the Arbitrator declared his acceptance of the terms. The Counsel for the Respondent received the award on 3 September 2013, in the late afternoon. On the same date, at 6:29 pm, the Counsel for the Appellant sent the Arbitrator a fax, in which he took notice of his resignation as arbitrator, in view of his failure to deliver the award before the expiry of the time limit and asked him to confirm the termination of his functions. In his reply (dispatched at 7:24 pm) the Arbitrator stated that the delivery was attempted but failed because the office of the Counsel for the Appellant was closed. The delivery of the package containing the award to the Counsel for the Appellant finally took place on 4 September 2013, and the Counsel wrote to the Arbitrator the following: "Receipt of this package does not imply acceptance of a possible arbitral award which may be contained therein, neither the acknowledgement of any validity of such documents. Geneva, 4 September 2013, 2:42 p.m.”.

In the procedure for setting aside the award before the Swiss Federal Supreme Court, the Appellant invoked Art 190 Para 2 (a) of the Swiss Code on International Private Law providing that the award may be challenged if the Sole Arbitrator was designated irregularly or the Arbitral Tribunal was constituted irregularly. Deciding on this matter, the Court found that the circumstances of the case clearly showed the joint will of both parties in the arbitral proceedings that the arbitration agreement terminates ipso facto on 2 September 2013, at 5:00 p.m. should either of them fail to receive the final award before this deadline, to which the Arbitrator explicitly agreed. In that regard, the Court held that the reason for the premature termination of the powers of the Arbitrator was not mere resignation by the Arbitrator or his removal by a joint decision of the two parties. To the contrary, the reason for the termination of the powers of the Arbitrator, in the view of the Court, had to be sought in a "tripartite" agreement entered into to this effect by each party with the other, on the one hand, and by both parties jointly with the Arbitrator, on the other hand. Hence the Court held that the award in dispu- 
te (dated 3 September 2013) was issued after the Arbitrator's mission terminated (on 2 September 2013).

In the statement of reasons, the Court pointed out that the Concordat on Arbitration of 1969 explicitly stated that an award could be annulled when the arbitral tribunal decided after the expiry of the time limit given to fulfil its mission - Art 36 (g). The present Swiss law did not contain such provision, and the Swiss legal doctrine, in its vast majority, considered that to be an issue of jurisdiction ratione temporis falling within Art 190.2 (b) of the Swiss Code on International Private Law, which provided that the award may be challenged if the arbitral tribunal decided erroneously on the matter of its own jurisdiction. In the light of that rule, it was considered that the Arbitrator arrogated to himself a jurisdiction he no longer had by issuing the award after his mission had terminated. Considering that the Appellant in the case at hand relied on Art 190 Para 2 (a), the Court held that the position of an arbitrator deciding beyond the time limit is not similar to that of an arbitrator who was not properly appointed; this is a case of an arbitrator the appointment of whom is beyond discussion, but who disregarded the time limit set to his jurisdiction. Thus, the Court found that the appeal was admissible and set aside the award for the grounds stated in Art 190 Para 2 (b) of the Swiss Code on International Private Law. ${ }^{76}$

When the time limit for making the award is not provided. - When the arbitration agreement, as well as the rules of the arbitration institution and the national law are silent about the time limit for making the award, in assessing such time limit it is necessary to consider first and foremost the duty of due care which the arbitrator assumes by accepting his appointment. This care, as already argued, involves the duty of conducting the proceedings efficiently. Therefore, while considering the circumstances of each particular case, it seems necessary to be guided by the standard of reasonable time within which the arbitrators are required to issue the award. ${ }^{77}$

\section{Adjudicating the dispute}

General rule. - An arbitrator who has accepted his appointment has the duty to adjudicate the dispute which had been entrusted to him to resolve and decide it. This duty is narrowly related to his judicial powers; just like a judge, an ar-

76 4A_490/2013 of 28 January 2014, available at: www.bger.ch.

77 See for example the European Convention for the Protection of Human Rights and Fundamental Freedoms from 1950, which adopts this standard and provides that: "Everyone is entitled to a fair and public hearing within a reasonable time by an independent and impartial tribunal established by law" (Art 6.1). 
bitrator is duty-bound to bring the arbitration to its conclusion, i.e. completion by issuing a final award. ${ }^{78}$ The duty to adjudicate the case also entails the arbitrator's power to decide himself about his own competence (compétence-compétence principle), ${ }^{79}$ and his power to order interim and conservatory measures upon a motion of a party to the dispute (unless otherwise provided for under the arbitration agreement and if permissible under lex arbitri) ${ }^{80}$ From the moment he has accepted his appointment, an arbitrator may not resign from the dispute without just cause.

National laws. - Some national laws contain explicit provisions to that effect. Thus for example under the French New Code of Civil Procedure, the arbitrators must proceed with their mission until it is completed and may only be removed with the parties' unanimous consent. ${ }^{81}$ The Dutch Code of Civil Procedure provides for a similar solution, stating that an arbitrator may, at his own request, be released from his mandate only subject to a consent of both parties or, in the absence thereof, by the competent Court. ${ }^{82}$ The Italian Code of Civil Procedure takes a step further by providing that an arbitrator shall be liable for damages if, after accepting his appointment, he should resign from office without just cause. ${ }^{83}$

Preventing obstructiosn in arbitration. - Ratio behind these rules is to prevent an arbitrator from obstructing the arbitration by resigning for unjustified causes. It is not entirely uncommon in the arbitration practice for an arbitrator, sensing that he will be outvoted by other members of the arbitral tribunal, to resign in order to prevent (or delay) the award against the appointing party. In such cases, the arbitrator as a rule should be replaced, which tends to significantly prolong the arbitration. In general, a resignation by an arbitrator before termination of the arbitration leads to serious impediments to the arbitration, and therefore the national laws and rules of arbitration institutions for the most part allow for

78 Including a ruling based on a settlement. See Art 47 of the Serbian Arbitration Law which specifies how arbitration proceedings may be terminated, as well as Art 54 providing for a ruling based on a settlement.

79 See Art 28 of the Serbian Arbitration Law. In details on this principle, J. Perović, Ugovor o međunarodnoj trgovinskoj arbitraži, op. cit., p. 159 ff.

80 See Art 15 and Art 31 of the Serbian Arbitration Law. On interim measures in arbitration in general, G. Knežević, V. Pavić, op. cit., pp. 129-133.
81 Art 1462.
82 Art 1029 Para 2.
83 Art 813 Para 2. 
such resignation solely for just causes. ${ }^{84}$ Furthermore, some rules require the resignation to be approved by the arbitration institution. ${ }^{85}$ Thus for example under the ICC Rules, an arbitrator may be replaced only upon acceptance of the resignation by the Court. ${ }^{86}$ It is noted in a comment to this rule that the Court may reject a resignation by the arbitrator in case it finds that the interests of the parties would be better served if the arbitrator should remain in office. ${ }^{87}$

Serbian Law. - Under the Serbian Arbitration law, an arbitrator may resign from duty by a written statement if for just cause, including the grounds for challenge, he is no longer able to perform his duties. ${ }^{88}$ The SA Rules provide that an arbitrator may resign if he becomes de jure or de facto unable to perform his duties or for other justifiable reasons fails to perform his duties within the appropriate time limit, ${ }^{89}$ thus it may be inferred that the resignation need not be approved by the SA. The Rules of the Belgrade Arbitration Centre adopt a similar solution (BAC Rules). ${ }^{90}$

Proceeding with arbitration in a truncated formation. - In an endeavour to reduce the cost and time of arbitration, and to prevent mala fidei resignation of arbitrators, the rules of some arbitration institutions provide for a possibility that an arbitrator need not necessarily be replaced should he resign from duty, but rather, under certain circumstances, the remaining arbitrators may proceed with the arbitration (truncated arbitral tribunal). Hence, under the Stockholm Rules,

84 In the arbitration practice, the just cause is deemed to exist in case of a conflict of interest (e.g. the arbitrator commenced employment with a law office that has a legal relationship with one of the parties to the dispute), illness, or personal problems of the arbitrator, acceptance by the arbitrator of a certain position or function that does not allow him to act as an arbitrator (e.g. he becomes a judge of the constitutional court or a public official), etc. In more details, J. Fry, S. Greenberg, F. Mazza, The Secretariat's Guide to ICC Arbitration, op. cit., p. 181.

85 See for example the DIS Rules - Art 16.1 (ii) or the Stockholm Rules, Art 20.1 (i).

86 See Art 15 (1) Rules.

87 Between 2001 and 2010, a total of 208 resignations were tendered before this Court, five of which were rejected by the Court. In one case from the Court's more recent practice, all three arbitrators offered to resign over continued disagreement between them. Considering the consequences of the withdrawal of the entire arbitral tribunal on arbitration proceedings, the Court accepted only the resignation of the Presiding Arbitrator, intending to defuse tension between the remaining two arbitrators, bearing in mind that they are familiar with the case in dispute. See commentary to Art 15 (1), J. Fry, S. Greenberg, F. Mazza, The Secretariat's Guide to ICC Arbitration, op. cit., p. 181.
88 Art 25 Para 1.
89 Art 24 Para 1.
90 Art 20 Para 1. 
where the arbitral tribunal consists of three or more arbitrators, in case of a termination of the mandate of an arbitrator, the Board may decide that the remaining arbitrators shall proceed with the arbitration; before the Board takes such decision, the parties and the arbitrators must be given an opportunity to submit comments on the issue. In deciding, the Board takes into account the stage of the arbitration and any other relevant circumstances. ${ }^{91}$ By the same token, under the DIS Rules, the Arbitration Council may decide that an arbitrator whose mandate has been terminated shall not be replaced if all of the parties and the remaining arbitrators so agree and after taking into account all of the circumstances. In such cases, the arbitration continues with the remaining arbitrators only. ${ }^{92} \mathrm{~A}$ similar solution is prescribed by the ICC Rules, stating that subsequent to the closing of the proceedings, instead of replacing an arbitrator whose mandate has terminated, the Court may decide, when it considers appropriate, that the remaining arbitrators shall continue the arbitration; in making such determination, the Court takes into account the views of the remaining arbitrators and of the parties and such other matters that it considers appropriate in the circumstances. ${ }^{93}$ Still, this rule is applicable only where the proceedings are closed; if the mandate of an arbitrator has terminated prior to the closing of the proceedings, under the ICC Rules such arbitrator must be replaced. ${ }^{94}$ These and similar solutions may prove useful, particularly when the arbitrator's intent in resigning is to block the arbitration and delay the award.

\section{Disclosure of potential conflict of interest}

Independence and impartiality. - Independence and impartiality are imperative in arbitration law. ${ }^{95}$ The international conventions, national laws on arbitration and the rules of arbitration institutes, all require an arbitrator to be and remain independent and impartial. ${ }^{96}$ It must logically follow from the fact that an

91 Art 21 (2).

92 Art 16.4 .

93 Art 15 (5).

94 See comment to Art 15 (5) of the ICC Rules, J. Fry, S. Greenberg, F. Mazza, The Secretariat's Guide to ICC Arbitration, op. cit., pp. 192-194; H. Verbist, E. Schäfer, Ch. Imhoos, op. cit., p. 97.

95 In details, Jelena Perović, "Sumnja u nezavisnost ili nepristrasnost arbitra kao osnov zahteva za njegovo izuzeće”, Pravni život, No. 11/2017, Beograd, 2017, pp. 63-78.

96 The European Convention for the Protection of Human Rights and Fundamental Freedoms of 1950 provides that: "Everyone is entitled to a fair and public hearing within a reasonable time by an independent and impartial tribunal established by law" (Art 6.1). In the same vein, the 
arbitrator adjudicates a dispute, that he must be perfectly independent and impartial of the parties and the dispute. This requirement applies to every arbitrator alike, to the sole arbitrator, the presiding arbitrator, and the arbitrators appointed by the parties. ${ }^{97}$ An arbitrator must be and remain independent during the entire course of arbitration, meaning from the time of his appointment until the final award is made ${ }^{98}$ or arbitration terminated otherwise. ${ }^{99}$

UN Universal Declaration of Human Rights of 1948 declares that: "Everyone is entitled in full equality to a fair and public hearing by an independent and impartial tribunal," (Art 10). While it may be open to debate whether or not these conventions apply directly to arbitration, there is no doubt that both public and private jurisdictions must be guided by the fundamental principles of these conventions, and that the state courts which are subject to these conventions, will in any case be required to apply these principles when deciding in the course of judicial review of the award (see Charles Jarrosson, "Larbitrage et la Convention européenne des droits de l'homme", Revue de l'arbitrage, 1989, pp. 573-607). In that regard, the view emphasized in literature is that independence and impartiality of arbitrators must essentially correspond to the fundamental standards provided under these conventions and that independence and impartiality of arbitrators are today the fundamental principles of the transnational public policy (D.Babić, op. cit., p. 672). Among the international conventions governing arbitration the Convention on the Settlement of Investment Disputes between States and Nationals of Other States of 1965 (Washington Convention - ICSID), provides for this principle stating that "Persons designated to serve shall be persons... who may be relied upon to exercise independent judgement" (Art 14.1). The requirement of independence and impartiality of the arbitrators is explicitly provided by the UNCITRAL Model Law - Art 12.2, the national laws governing arbitration, particularly those modelled on the UNCITRAL Model Law, the UNCITRAL Rules of Arbitration of 1976 as revised in 2010 in Art 12.1 (hereinafter: UNCITRAL Rules of Arbitration), as well as the rules of all reputable institutional arbitrations. Detailed comparative law study, The Arbitral Process and the Independence of Arbitrators, ICC Publication, No. 472, Paris 1992; Karel Daele, Challenge and Disqualification of Arbitrators in International Arbitration, Kluwer Law International BV, The Netherlands, 2012; Aldo Berlinguer, "Impartiality and Independence of Arbitrators in International Practice", The American Review of International Arbitration (ARIA), Vol. 6 No. 4, 1995; Dominique Hascher, "Independence and Impartiality of Arbitrators: 3 Issues", American University International Law Review 27, No. 4, 2012, pp. 789-806.

97 For more details, J. Perović, "Sumnja u nezavisnost ili nepristrasnost arbitra kao osnov zahteva za njegovo izuzeće”, op. cit., p. $65 \mathrm{ff}$.

98 Including the time required for any corrections, additions and interpretations of the award. See explanation to the General Standard 1 of IBA Guidelines on the Conflicts of Interest in International Arbitration, adopted on 23 October 2014, p. 4.

99 This requirement has gained broad acceptance in comparative arbitration law by establishing the duty of an arbitrator to disclose to the parties any circumstances likely to give rise to justifiable doubts as to his impartiality or independence; the duty of disclosure exists both before and after the acceptance of appointment as an arbitrator, in other words from the time of the appointment and throughout the arbitral proceedings, where such circumstances have arisen upon his appointment. In that regard see for example the UNCITRAL Model Law, Art 12.1, the UNCITRAL Arbitration Rules, Art 11, the ICC Rules, Art 11(1), 11 (2) and 11(3), the Swiss Rules Art 9, etc. The Serbian Arbitration Law provides for this rule in Art 21 specifying the duty of a person nominated as 
Independence and impartiality, as qualities required from arbitrators, do not lend themselves easily to strict definitions. Essentially, independence is a situation of fact or law capable of objective verification, while impartiality is more of a state of mind, a psychological state subjective in its nature. According to the doctrine, "it is generally recognised that (arbitrator's) "dependence" is linked solely to the issues arising from the relationship between the arbitrator and one of the parties, financial or otherwise". Hence, independence is assessed according to the objective criteria. By contrast, impartiality is connected to the obvious bias of an arbitrator either in favour of one of the parties or in relation to the issues in dispute, and is therefore a subjective and abstract concept. ${ }^{100}$ What is essentially of greatest importance is that the arbitrator remains impartial, i.e. decides the dispute objectively, guided solely by the law and relevant facts of the case, and not by the bias in favour of a party.101

As to how this issue is addressed in the Serbian law, the Arbitration Law provides that an arbitrator must be impartial and independent of the parties and the issue in dispute. ${ }^{102}$ Furthermore, the requirement of independence and impartiality is contained in the provisions concerning the duty of an arbitrator to disclose to the parties any facts that may justly raise doubts as to the arbitrator's independence and impartiality, ${ }^{103}$ and the provisions concerning the challenge of arbitrators. ${ }^{104}$ The SA Rules and the BAC Rules provide for independence and impartiality of arbitrators within the provisions concerning the acceptance of appointment and the challenge of arbitrators. ${ }^{105}$

Duty of disclosure. - Considering the importance of independence and impartiality of an arbitrator, the sources of arbitration law set down that an arbitrator is required to disclose to the parties and the arbitration institution or the appointing authority in ad hoc arbitration, any facts and circumstances that may

an arbitrator to disclose, before accepting the appointment, the facts that may justly give rise to doubts as to his impartiality or independence. Furthermore, an arbitrator is required, from the day of his appointment, to disclose without delay such facts that may arise after his appointment. A similar provision is contained in the BAC Rules in Art 19.1 and 19.2, while the SA Rules explicitly provide for the duty of disclosure only prior to accepting appointment as an arbitrator (Art 20).

${ }^{100}$ N. Blackaby and C. Partasides with A. Redfern and M. Hunter, op. cit., p. 268.

101 See D. Babić, op. cit., p. 674.

102 Art 19.3.

103 Art 21.

104 Art 23.

105 The Rules of the Permanent Arbitration at the Chamber of Commerce of Serbia, Art 20.1 and Art 23.1, the BAC Rules, Art 19 and Art 21.1. 
give rise to any doubts as to his independence and impartiality. The duty of disclosure exists both before and after the acceptance of the appointment as an arbitrator, from the date of the appointment and through entire arbitration, where such circumstances have arisen upon his appointment. ${ }^{106}$ In case of a breach of this duty, an arbitrator may be held liable for damages, particularly, if due to the breach of this duty, certain actions already taken in the arbitration proceedings involving such arbitrator need to be repeated. ${ }^{107}$ This issue will be further discussed in the section addressing the legal consequences of a breach of a duty of an arbitrator.

The duty of disclosure of such circumstances prior to accepting the appointment as an arbitrator is essentially a preventive measure allowing the parties to challenge the appointment of an arbitrator who, in their opinion, fails to meet the requirements of independence and impartiality. If an arbitrator, before accepting to serve, discloses all the circumstances that may be deemed relevant for the assessment of his independence and impartiality, and the parties fail to submit a timely objection to his appointment, the notice of his challenge based on the same grounds after his appointment as a rule should not be admissible. Hence this measure assists the parties in selecting an appropriate arbitrator and avoiding the risk of challenge in further course of arbitration. ${ }^{108}$

This duty is universally acknowledged in arbitration law. The UNCITRAL Model Law, for example, provides under Art 12.1 that: "When a person is approached in connection with his possible appointment as an arbitrator, he shall disclose any circumstances likely to give rise to justifiable doubts as to his

106 In the context of the duration of the requirement of independence and impartiality of an arbitrator, it should be noted that, in some cases, the circumstances arising after making the award may imply lack of independence or impartiality of an arbitrator during the arbitration proceedings. Thus, for example, the Paris Court of Appeals found in one case that an employment contract signed by an arbitrator with one of the parties one day after making his award implied that he had prior relations with the party which subsequently became his employer, which raised doubts as to his independence and impartiality (CA Paris, 9 Apr 1992, Annahold BN v. L'Oréal, 1996 Revue de l'arbitrage, 483, cit. from E. Gaillard, J. Savage (editors), Fouchard Gaillard Goldman On International Commercial Arbitration, op. cit., pp. 572 and 565).

107 B. Berger, F. Kellerhals, op. cit., p. 347.

108 It should be noted that disclosure of such circumstances by an arbitrator does not in itself imply admission to a conflict of interest. It is assumed that an arbitrator who has declared such circumstances considers himself to be independent and impartial regardless of such circumstances; otherwise, such arbitrator would have refused his appointment. In other words, the purpose of this exercise is to allow the parties to assess the circumstances relevant to independence and impartiality of the arbitrator who has notified them thereof and to reach, in the light of such circumstances, an appropriate decision as to such arbitrator's appointment. 
impartiality or independence.... ${ }^{109}$ An almost identical rule is contained in the UNCITRAL Arbitration Rules. ${ }^{110}$ Most national laws governing arbitration provide in a similar manner for the duty of disclosure by an arbitrator, ${ }^{111}$ including the Serbian Arbitration Law specifying that: "A person proposed for an arbitrator is obliged to disclose, before accepting the duties of an arbitrator, the facts that may justly raise doubts as to his impartiality or independence". 112 This duty is laid down in all recent rules of institutional arbitrations. ${ }^{113}$ By accepting the standard of "justifiable doubts" as to arbitrator's impartiality or independence, these rules essentially adopt, with slight variations, the objective criterion for identifying the circumstances an arbitrator must disclose in the context of his independence and impartiality.

In this context, the ICC Rules deserve special attention as their solution to the acceptable standard of assessing the circumstances to be disclosed differs from most other sources of arbitration law. Under the Rules, a prospective arbitrator, before his appointment or confirmation, must sign a statement of acceptance, availability, impartiality and independence. He must disclose in writing to the Secretariat any facts or circumstances which might be of such a nature as to call into question the arbitrator's independence in the eyes of the parties, as well as any circumstances that could give rise to reasonable doubts as to the arbitrator's impartiality. ${ }^{114}$ The phrasing "in the eyes of the parties" suggests that the ICC Rules in this regard apply a subjective standard, and that the circumstances relevant to independence and impartiality of an arbitrator are assessed from the standpoint of the parties. ${ }^{115}$ Hence, in assessing the circumstances of importance to the-

109 See comment to this rule in UNCITRAL 2012 Digest of Case Law on the Model Law on International Commercial Arbitration, p. $65 \mathrm{ff}$.

110 Art 11.

111 Comparative law study, E. Gaillard, J. Savage (editors), Fouchard Gaillard Goldman On International Commercial Arbitration, op. cit., pp. 577-580.

112 Art 21.1. It is argued in domestic literature that the phrasing of the Law enjoining an arbitrator to disclose the facts "that may justly give rise to doubts" implies a broader duty than that required by the rules of the UNCITRAL Model Law and the UNCITRAL Rules as it covers "not only the facts "likely" to give rise to justifiable doubts, but also those vaguely likely to give rise to such doubts" (G. Knežević, D. Pavić, op. cit., p. 94).

113 Including the SA Rules (Art 20) and the BAC Rules (Art 19.1). Detailed comparative law study of the solutions offered by the rules of international arbitrations, K. Daele, op. cit., pp. 1-63.

114 Art 11 (2).

115 See detailed comment to this rule in J. Fry, S. Greenberg, F. Mazza, op. cit., pp. 122-127; H. Verbist, E. Schäfer, Ch. Imhoos, op. cit., p. 65 ff. 
ir independence and impartiality, arbitrators must take into account the respective standpoints of the parties. ${ }^{116}$

\section{Confidentiality}

Confidentiality as an advantage of arbitration. - Traditionally, confidentiality is mentioned among the major advantages of arbitration over litigation. It is exactly the confidentiality afforded by the arbitration, held unlike the litigation, "behind the closed doors", that primarily attracts business people to this method of dispute resolution. That way, they can keep away from the public the data relevant to their operations, business secrets, intellectual property and the dispute itself. $^{117}$

Duty of confidentiality. - By accepting his appointment, an arbitrator, as a rule undertakes to keep confidential all the information and data relating to the arbitration and the award. Hence, an arbitrator must not disclose to any third parties any information about the identity of the parties, or any data related to the arbitration and the award. The duty of confidentiality may be specifically provided by the arbitration agreement or receptum arbitrii, although it is often set forth in the rules of arbitration institutions and the codes of ethics. ${ }^{118}$ An arbitrator who breaches the duty of confidentiality may be held liable to the parties for damages. ${ }^{119}$

Rules of arbitration institutions. - The duty of confidentiality, as provided for in the rules of arbitration institutions, is often not limited to the arbitrators, but

116 This issue is addressed in great detail by the Guidelines on Conflicts of Interest in International Arbitration adopted by the International Bar Association (IBA Rules) which, similar to the ICC Rules, adopt a subjective criterion for identifying the circumstances a prospective arbitrator is required to disclose. Under General Standard 3 of the Guidelines, if facts or circumstances exist that may, in the eyes of the parties, give rise to doubts as to the arbitrator's impartiality or independence, the arbitrator shall disclose such facts or circumstances to the parties, the arbitration institution or other appointing authority in ad hoc arbitration and other members of the arbitral tribunal, prior to accepting his appointment or thereafter, as soon as he learns of them (General Standard 3 a). Any doubt as to whether an arbitrator should disclose certain facts or circumstances should be resolved in favour of disclosure (General Standard 3 b).

117 See N. Blackaby and C. Partasides with A. Redfern and M. Hunter, op. cit., pp. 33-34 and 136-143; Jelena Perović, Milena Đorđević, "Resolution of Commercial Disputes Through Arbitration as a Contribution to Improvement of Business Environment in Serbia", Ekonomika preduzeća, March-April 2013, Beograd, 2013, p. 249.

118 Study of these solutions, E. Gaillard, J. Savage (editors), Fouchard Gaillard Goldman On International Commercial Arbitration, op. cit., p. 612; N. Blackaby and C .Partasides with A. Redfern and M. Hunter, op. cit., p. $136 \mathrm{ff}$.

119 See B. Berger, F. Kellerhals, op. cit., pp. 350-351. 
also applies to the parties and their counsels, as well as the arbitration institution itself. ${ }^{120}$ On the other hand, the ICC Rules do not treat the duty of confidentiality as a general rule. They provide that the arbitral tribunal may, upon a request of any party, make orders concerning the confidentiality of the arbitration proceedings or of any other matters in connection with the arbitration and may take measures for protecting trade secrets and confidential information. ${ }^{121}$ In contrast to the rules of other arbitration institutions which consider confidentiality to be a general rule, with certain variations, the ICC Rules adopt a more flexible approach, leaving it to the parties and the arbitral tribunal to decide this issue based on the circumstances of the case at hand. ${ }^{122}$ At the ICC Court of Arbitration, the confidentiality obligation as a general rule applies only to the work of the Court. ${ }^{123}$ Comments to these Rules acknowledge that the Court and Secretariat keep confidential all information and documents acquired in connection with the dispute, as well as the information about their own work; they will not even confirm the existence of a dispute to any parties not involved in the dispute. ${ }^{124}$

Confidentiality of deliberations. - The confidentiality obligation applies also to the deliberations of the arbitral tribunal, which means that an arbitrator is required not to communicate to the parties to the dispute or the third parties any information about the course and stages of deliberation, or the results of deliberations and voting. On the other hand, an arbitrator who is not in agreement with the position of the majority may submit a dissenting opinion, and the award may state if it was reached unanimously or by majority of votes. With regard to the confidentiality of deliberations of the arbitral tribunal, Swiss authors take the view that, under extraordinary circumstances, it is possible for an arbitrator to notify the parties of certain aspects of deliberations without consent of other members of the tribunal - for example of refusal by one of the arbitrators to participate in deliberations, ${ }^{125}$ and of breaches of the rules of procedure or of

120 See for example the Swiss Rules, Art 44.1; the Milan Rules, Art 8.1; the DIS Rules, Art 44.1 etc. The BAC Rules contain a precisely defined provision to that effect, namely that "The BAC, parties, arbitrators, witnesses and experts are required to keep the proceedings and the arbitral awards confidential to the extent this is not inconsistent with the applicable mandatory rules or the need to protect one's personal rights" (Art 9 Para 1).

121 Art 22 (3).

122 J. Fry, S. Greenberg, F. Mazza, op. cit., p. 235.

123 Internal Rules of the International Court of Arbitration, Art 1.

124 J. Fry, S. Greenberg, F. Mazza, op. cit., p. 235.

125 See in that regard Art 30.2 LCIA Rules. 
fraudulent actions by other members of the tribunal. ${ }^{126}$ This paper supports this view, and further argues that invoking the duty of confidentiality must not serve as a protective "veil" or justification to conceal from the parties any misconduct (or omission) by the members of the arbitral tribunal. It should be noted that a breach of the obligation to keep deliberations confidential may trigger an arbitrator's liability for damages just like a breach of the duty of confidentiality in general. ${ }^{127}$ On the other hand, the Serbian law takes the view that a breach of the duty to keep deliberations confidential as a rule does not in itself constitute grounds for setting aside the award. However, the grounds for setting aside would exist if during the arbitration, one party, due to a breach of the duty of confidentiality by an arbitrator, were placed in a privileged position, in violation of the principle of equality of the parties. ${ }^{128}$

Confidentiality of the award. - Arbitrators are required to keep the award confidential, i.e. not to disclose the award either in full or in part, unless otherwise agreed by the parties. The rules of arbitration institutions adopt a somewhat more flexible approach to the issue by allowing for the award to be published in principle subject to expunging any reference to the parties and obtaining the parties' prior approval. ${ }^{129}$

The Swiss Rules lay down detailed provisions to that effect, specifying that an award may be published, whether in its entirety or in the form of excerpts or a summary, only under the following conditions: that a request for publication is addressed to the Secretriat; that all references to the parties' names are deleted; and that no party objects to such publication within the time limit fixed for that purpose by the Secretariat. ${ }^{130}$ Speaking of confidentiality of an award made under the auspices of the ICC Court of Arbitration, a commentary to the ICC Rules states that the Court and the Secretariat do not provide the award to any natural or legal persons other than the parties, their counsels and arbitrators, while within the Court of Arbitration itself, the award is accessible only to the Secretariat staff. However, the Court may publish excerpts from the award, after having deleted the names of the parties and all references enabling their identification, unless the parties agree to exclude the possibility of publication. ${ }^{131}$ The LCIA Rules provi-

126 B. Berger, F. Kellerhals, op. cit., pp. 518-519.

127 See B. Berger, F. Kellerhals, op. cit., pp. 519.

128 See Art 33 and Art 58 Para 4 of the Arbitration Law.

129 See for example the DIS Rules, Art 44.3, the Milan Rules, Art 8.2; the BAC Rules, Art 9 Para 2.

130 Art 44 Para 3.

131 See J. Fry, S. Greenberg, F. Mazza, op. cit., p. 342. 
de for particularly strict provisions on publication of the award, requiring a prior consent of both the parties and the arbitral tribunal. ${ }^{132}$ The duty of confidentiality of the award is also contained in the UNCITRAL Arbitration Rules, stipulating that an award may be made public only with the consent of all parties. ${ }^{133}$

\section{LEGAL CONSEQUENCES OF BREACHES OF ARBITRATOR'S DUTIES}

General division. - In very general terms, a distinction may be drawn between the legal consequences of a breach of an arbitrator's duty which affect the award and those which affect the arbitrator himself.

Setting aside an award. - A breach of a duty of an arbitrator may give rise to setting aside an award where such breach of duty constitutes grounds for setting aside the award under the applicable law in each particular case. In the Serbian law, this issue is governed by Article 58 of the Arbitration Law.

Legal consequences affecting an arbitrator. - Legal consequences affecting the arbitrator himself may include termination of his functions on the one hand and his civil liability on the other. A breach of certain duties (for example those relating to independence and impartiality) may also trigger a criminal liability of the arbitrator, which will not be addressed herein.

Termination of the mandate of an arbitrator. - The possibility of termination of arbitrators' functions due to non-performance is widely accepted in the sources of the arbitration law. Thus, under the UNCITRAL Model Law if an arbitrator becomes de jure or de facto unable to perform his functions or for other reasons fails to act without undue delay, his mandate terminates if he withdraws from office or if the parties agree on the termination. Otherwise, if the parties fail to agree on any of these grounds any party may request the court or another competent authority to decide on the termination of the mandate of the arbitrator; no appeal is admissible against such decision. If an arbitrator withdraws from his office or the parties agree to the termination of his mandate under these rules or the rules of the challenge procedure, this does not imply acceptance of the validity of any grounds for termination of the mandate of the arbitrator. ${ }^{134}$ The grounds for termination of arbitrators' functions are expressed in similar terms in national arbitration laws, rules of arbitration institutions, as well as the UNCITRAL Arbitration

132 Art 30.3 .

133 See Art 34 Para 5 in full.

134 Art 14 (1). 
Rules. ${ }^{135}$ The Serbian Arbitration Law sets down almost identical rules on termination as the UNCITRAL Model Law, ${ }^{136}$ and the SA Rules, ${ }^{137}$ and the BAC Rules also provide for similar solutions in that respect. ${ }^{138}$

Civil liability of an arbitrator. - The legal relationship between an arbitrator and the parties is governed under a contract they conclude - receptum arbitrii. In case of a breach of the duties which an arbitrator undertakes by accepting his appointment, the grounds for arbitrator's civil liability will be found in this contract. The key issue with regard to the civil liability of an arbitrator is whether the arbitrator should be held liable for non-fulfilment of his contractual obligations in compliance with the general rules governing contractual liability, or should be "exempt" from this kind of liability based on his judicial function. In addressing this issue, a distinction must be drawn between the duties of an arbitrator arising directly from his judicial function and other duties undertaken by an arbitrator by accepting his mandate. The issue must be viewed in the light of the applicable law in each particular case.

Principle of immunity for actions directly related to judicial powers. - Drawing on the judicial powers granted to an arbitrator to adjudicate a dispute, akin to a judge of a state court, the arbitration law widely accepts the principle that an arbitrator as a rule is not held liable for the actions directly related to the exercise of his judicial function, i.e. to the award he has rendered (e.g. for erroneous application of the substantive law or erroneous appraisal of facts). ${ }^{139}$ This principle essentially seeks to protect an arbitrator in the exercise of his judicial function and limit the parties in bringing an action against the arbitrator in personam, over and above an action to set the award aside. Such conduct of the parties would have a negative impact on legal security, not only in each particular case, but also for arbitration in general. ${ }^{140}$

The so-called principle of immunity, whereby arbitrators as a rule are not held liable for the actions stemming directly from their judicial function, is particularly recognised in the common law countries. In the United States, the civil liability of arbitrators for acts committed in the course of performance of their

135 Comparative law study, E. Gaillard, J. Savage (editors), Fouchard Gaillard Goldman On International Commercial Arbitration, op. cit., pp. 617-618.

136 Art 25.

137 Art 24.

138 Art 20.

139 M. Stanivuković, op. cit., p. 181.

140 In details, E. Gaillard, J. Savage (editors), Fouchard Gaillard Goldman On International Commercial Arbitration, op. cit., p. 592 ff. 
functions is excluded, and the case law affords broadest protection from any actions filed against them on these grounds. ${ }^{141}$ Under the English law, arbitrators are not held liable for the performance of their functions, unless they acted in bad faith, ${ }^{142}$ and similar solutions have been adopted in Canada, New Zealand and Australia. ${ }^{143}$ By contrast, in most countries of the continental legal tradition, the law is silent on this issue. In the absence of legal provisions, the issue is left to the court practice which tends to address it by applying the general rules of the law of obligations while considering the general principles of arbitration and the relevant circumstances of each particular case. However, the prevailing view in the case law and doctrine of the civil law countries recognises the principle of immunity with certain limitations. ${ }^{144}$

This principle is clearly recognised in the French case law. ${ }^{145}$ Thus, for example, in a case before the Reims Tribunal of First Instance, a party brought an action against the arbitrators for damages it claimed to have suffered as a result of their award. Deciding in the dispute, the court dismissed the claim, stating that all of the claimant's arguments essentially amounted to the general criticism that the arbitrators reached the wrong decision. The arbitrators could incur liability only in the event of gross negligence, fraud, or bias in favour of one of the parties. Otherwise the protection, independence and authority of the arbitrators would be restricted to an extent that would be incompatible with their judicial function. The court took a further step and upheld the arbitrators' counterclaims for damages against the claimant. ${ }^{146}$ In another case against arbitrators for damages, where the claimant alleged a breach of the applicable procedural rules, the Paris Tribunal of First Instance took a similar position, emphasizing the need to protect the arbitrators' authority and dignity. In that regard, the Tribunal found that a

141 See N. Blackaby and C. Partasides with A. Redfern and M. Hunter, op. cit., p. 330.

142 The English Arbitration Act, Art 29. On immunity of arbitrators in the English law, M.L. Smith, op. cit., p. $31 \mathrm{ff}$.

143 See N. Blackaby and C. Partasides with A. Redfern and M. Hunter, ibidem.

144 Comparative law study, The Arbitrator's Liability Report from the Club des Juristes, Ad hoc Commitee, June 2017, Paris, 2017, p. 22 ff; N. Blackaby and C. Partasides with A. Redfern and M. Hunter, op, cit., pp. 330-333; E. Gaillard, J. Savage (editors), Fouchard Gaillard Goldman On International Commercial Arbitration, op. cit., ibidem.

145 Several judgements by the French courts in this context are referred to and examined in The Arbitrator's Liability Report from the Club des Juristes, op. cit., p. $23 \mathrm{ff}$.

146 TGI Reins, 27 September 1978, cit. from E. Gaillard, J. Savage (editors), Fouchard Gaillard Goldman On International Commercial Arbitration, op. cit., pp. 590-591. 
party is not entitled to claim damages on the grounds of the allegations that arbitrators made a wrong award. ${ }^{147}$

Limits to the principle of immunity. - No national legal system allows the principle of immunity in the literal sense of the word and absolutely. In fact, legal systems recognise limitations to this principle, defining the cases where an arbitrator cannot rely on his immunity. These limitations may be grouped round two categories: general limitations where an arbitrator has wilfully violated his obligations and special limitations for breaches of the duty to disclose a conflict of interest. ${ }^{148}$

The principle of immunity is generally subject to limitations where the breach of duty by an arbitrator arises as a result of his deliberate fault or fraudulent conduct. Although there are some variations in the treatment of this issue in legislation, case law, and doctrine of the comparative law (focusing sometimes on the requirement for fraud, or deliberate fault, ${ }^{149}$ or sometimes on bad faith in the sense of deliberate fault $\left.{ }^{150}\right),{ }^{151}$ there is a broad agreement that any intentional fault or fraudulent conduct of an arbitrator in the discharge of his functions will mean a breach of his duty to conduct the proceedings in good faith and treat the parties equally. In such case, the arbitrator will be exempt from the principle of immunity and held liable for the damage incurred by the parties.

On the other hand, considering the importance of independence and impartiality of an arbitrator, the sources of arbitration law, as already shown, require an arbitrator to disclose a potential conflict of interest to the parties and the arbitration institution or the appointing authority in ad hoc arbitration. A breach of

147 Judgement Castin v. Gomez, 2 October 1985, cit. from ibidem.

148 This categorisation is adopted in E. Gaillard, J. Savage (editors), Fouchard Gaillard Goldman On International Commercial Arbitration, op. cit., p. 594 ff.

149 Certain court rulings and doctrines add gross negligence to deliberate fault. It is however open to debate whether gross negligence may lead to civil liability of an arbitrator (see E. Gaillard, J. Savage (editors), Fouchard Gaillard Goldman On International Commercial Arbitration, op. cit., pp. 598-599).

150 As already shown, the English Arbitration Act (Art 29) provides that an arbitrator is not liable for the discharge of his functions unless he acts in bad faith. The English doctrine interprets the term "bad faith" in this context as deliberate actions on part of the arbitrator. See Mustill \& Boyd, 2nd edition, 2001 Companion, p. 300 (cit. from The Arbitrator's Liability Report from the Club des Juristes, op. cit., p. 111) stating: "the concept of dishonesty (or bad faith, to use the terminology of section 29) involves, we consider, conscious and deliberate fault on the part of the arbitrator."

151 Detailed comparative law study, The Arbitrator's Liability Report from the Club des Juristes, op. cit. as a whole. 
this duty will render the arbitrator liable to the parties for damages. ${ }^{152}$ This is particularly true of the cases where the parties suffer additional costs and waste of time due to such breach, for example when certain steps in the arbitration proceedings need to be repeated ${ }^{153}$ or the procedure for setting aside the award is set in motion.

Liability for contractual obligations of an arbitrator. - Although an arbitrator enjoys a degree of immunity as concerns the award he makes, he is liable for failure to perform the contractual obligations he assumed by accepting his appointment. ${ }^{154}$ These are the duties relating to the manner of conducting the arbitration, that have been addressed herein. In this context, an arbitrator who fails to perform his obligations as agreed (directly in the arbitration agreement or indirectly - by accepting the rules of an arbitration institution or selecting an applicable law or a set of rules), is held liable for damages within the meaning of the general rules of the law of obligations, except where such liability is excluded under the contract.

The national laws governing arbitration are usually silent on the matter of civil liability of arbitrators. An exemption in that regard is the Austrian Code of Civil Procedure, which sets down that an arbitrator who does not fulfil the duty assumed by acceptance of the appointment, or does not fulfil it in a timely manner, shall be liable towards the parties for all damage caused by his culpable refusal or delay. ${ }^{155}$ Along the same lines, the Italian Code of Civil Procedure, whose solutions have been discussed herein, provides that the arbitrators shall be held liable for damages not only in case of resigning without just cause, but also if their award was set aside due to the missed time limit. ${ }^{156}$ However, in spite of the absence of explicit legal provisions, case law and doctrine in most countries take a firm view that arbitrators may incur civil liability ${ }^{157}$ due to a breach of duties rela-

152 See relevant judgements of the French courts, E. Gaillard, J. Savage (editors), Fouchard Gaillard Goldman On International Commercial Arbitration, op. cit., pp. 594-597.

${ }^{153}$ For example, in cases of removal of an arbitrator.

154 This view is widely accepted in comparative law. See The Arbitrator's Liability Report from the Club des Juristes, op. cit., p. 33 ff; B.Berger, F.Kellerhals, op. cit., p. 351; Russell on the Law of Arbitration, Walton and Vitoria Eds., $20^{\text {th }}$ ed., Stevens and Sons, 1982, op. cit., p. 121 ff; E. Gaillard, J. Savage (editors), Fouchard Gaillard Goldman On International Commercial Arbitration, op. cit., p. 619; N. Blackaby and C. Partasides with A. Redfern and M. Hunter, op. cit., p. 331 ff.

155 Art 594 Para 4.

156 Art 813 Para 2.

157 In this context, certain authors suggest that a distinction must be drawn between the obligations owed by an arbitrator that belong to the obligations of result - obligations de résultat and those considered to be the obligations of means - obligations de moyens (on distinction betwe- 
ting to the conduct of arbitration. ${ }^{158}$ Hence, arbitration institutions are increasingly introducing clauses on exemption or limitation of liability of arbitrators and arbitration institutions themselves. ${ }^{159}$

\section{CONCLUSION}

The examination of the duties of arbitrators made herein points to several conclusions. In the first place, the legal relationship between an arbitrator and the parties is governed by a contract entered into by and between them. It is based on this agreement that the arbitrators acquire rights and assume obligations relevant to the arbitration. An arbitrator must be independent and impartial of the parties and the subject matter of the dispute and must comply with the basic principles of the arbitration proceedings. These are the principal and universally acknowledged duties of arbitrators stemming from their judicial powers, the breach of which will result in setting aside the award. By accepting the appointment, an arbitrator assumes a series of other duties in arbitration. The most important of these include:

1) due care involving the duty of an arbitrator to devote sufficient time to the dispute he was appointed to, as well as to apply the knowledge, expertise and skills required of him for the analysis and resolution of disputable issues in the case at hand. An arbitrator must conduct the arbitration efficiently and observe the procedural time limits, and in particularly the time limit set for rendering the award;

en the obligations of result and the obligations of means in general, S. Perović, op. cit., pp. 90-94). Thus, for example, an arbitrator who has resigned without just cause, or has failed to meet or extend the deadline for issuing the award, has breached the obligation of result, and should be liable for damages due to the failure to achieve the result intended in assuming the obligation. As for the obligations owed by an arbitrator that belong to the obligations of means, an arbitrator may incur liability only for failing to perform such obligations with due care (see E. Gaillard, J. Savage (editors), Fouchard Gaillard Goldman On International Commercial Arbitration, op. cit., p. 621). This approach, however, has been criticized in the doctrine, the argument being that the above distinction between obligations may not be successfully translated from the classical law of obligations to arbitration, above all because in arbitration it is difficult to draw a clear distinction between the obligations of result and the obligations of means (see. The Arbitrator's Liability Report from the Club des Juristes, op. cit., p. 33).

158 Comparative law study in that respect, The Arbitrator's Liability Report from the Club des Juristes, ibidem.

159 See for example the ICC Rules, Art 41, the LCIA Rules, Art 31, the Stockholm Rules, Art 52, the DIS Rules, Art 45, etc. 
2) adjudication of the dispute, which means that an arbitrator is required to bring the arbitration to its conclusion, i.e. termination by issuing a final award. From the time of accepting the appointment, an arbitrator may not resign from the dispute without just cause. This principle, intending first of all to prevent an arbitrator from obstructing the proceedings by resigning for unjustified causes, is widely accepted in the rules of arbitration institutions;

3) disclosure of a potential conflict of interest stemming from the universally accepted requirement for independence and impartiality of an arbitrator. Sources of arbitration law require an arbitrator to disclose to the parties and the arbitration institution or the appointing authority in ad hoc arbitration, all the facts and circumstances that may give rise to any doubts as to his independence and impartiality. The duty of disclosure exists both before and after the acceptance of appointment as an arbitrator, from the date of the appointment and through entire arbitration, where such circumstances have arisen upon his appointment;

4) confidentiality which means that an arbitrator, by accepting the appointment, as a rule undertakes to keep confidential all the information and data relating to the arbitration and the award. An arbitrator must not disclose to any third parties any information about the identity of the parties to the dispute, or any data related to the arbitration and the award. The duty of confidentiality may be explicitly provided into the arbitration agreement or receptum arbitrii, although it is often set forth in the rules of arbitration institutions and the codes of ethics.

Legal consequences of breaches of arbitrator's duties may be divided into those affecting the award and those affecting the arbitrator himself. A breach of an arbitrator's duty may give rise to setting aside an award where such breach of duty constitutes grounds for setting aside of an award under the applicable law. The legal consequences affecting the arbitrator himself may include termination of his function on the one hand and his civil liability on the other.

The key issue with regard to the civil liability of an arbitrator is whether an arbitrator should be held liable for the non-fulfilment of his contractual obligations in line with the general rules of the law of obligations governing contractual liability, or should be "exempt" from this kind of liability based on his judicial function. In addressing this issue, a distinction is drawn between the duties of an arbitrator arising directly from his judicial function and other duties undertaken by an arbitrator by accepting his mandate. The arbitration law widely accepts the principle that an arbitrator as a rule is not held liable for the actions directly related to the exercise of his judicial function, meaning the award he made (the principle of immunity). This principle, however, is subject to significant limitations, particularly where a breach of duty by an arbitrator arises as a result of his delibe- 
rate fault or fraudulent conduct. On the other hand, an arbitrator is liable for the failure to perform the contractual obligations he assumed by accepting his appointment, relating to the manner of conducting the arbitration. In this context, the prevailing view is that an arbitrator who fails to perform his obligations as agreed is held liable for damages within the meaning of the general rules of the law of obligations, except where such liability is excluded under the contract.

The duties owed by arbitrators and the legal consequences of their breaches examined herein will determine to a great degree the course of arbitration and the grounds for any appropriate court actions following the issue of the award.

\section{Prof. dr JELENA S. PEROVIĆ VUJAČIĆ}

Predsednik Kopaoničke škole prirodnog prava - Slobodan Perović, redovni profesor Ekonomskog fakulteta Univerziteta u Beogradu

\section{OBAVEZE ARBITARA U MEĐUNARODNOJ TRGOVINSKOJ ARBITRAŽI}

\section{Rezime}

Predmet rada predstavlja analiza obaveza arbitara u međunarodnoj trgovinskoj arbitraži. U uvodnom delu učinjen je pogled na pravni odnos između arbitara i strana u sporu uređen ugovorom koji se između njih zaključuje. Centralni deo analize posvećen je obavezama koje arbitar preuzima prihvatanjem svog imenovanja. U tom kontekstu, pažnja je usmerena na: a) osnovne obaveze koje se ogledaju u zahtevu da arbitar bude nezavisan i nepristrasan i da poštuje osnovna načela arbitražnog postupka, i b) druge najznačajnije obaveze arbitra: dužna pažnja, efikasnost i poštovanje roka za donošenje arbitražne odluke, obaveza presuđenja spora, obaveza obaveštenja o mogućem sukobu interesa i obaveza poverljivosti. Nakon analize obaveza arbitara, razmatrane su moguće pravne posledice njihove povrede: poništaj arbitražne odluke, prestanak dužnosti arbitra i građanskopravna odgovornost arbitra. Analiza pomenutih pitanja učinjena je sa stanovišta odgovarajućih rešenja uniformnih pravila i nacionalnih zakona iz oblasti arbitraže, pravilnika vodećih arbitražnih institucija, kao i stavova doktrine i međunarodne sudske i arbitražne prakse.

Ključne reči: arbitar, obaveza, arbitraža, arbitražni ugovor, arbitražni postupak

\section{Bibliography}

Babić Davor, “Nezavisnost i nepristrasnost arbitara”, Pravo u gospodarstvu (PUG), 3/2008, Zagreb.

Berger Bernhard, Kellerhals Franz, International and Domestic Arbitration in Switzerland, Third edition, Berne, 2015. 


\section{J. S. Perović Vujačić: Obligations of Arbitrators in International Commercial Arbitration}

Berlinguer Aldo, "Impartiality and Independence of Arbitrators in International Practice", The American Review of International Arbitration (ARIA), Vol. 6, No. 4, 1995.

Blackaby Nigel and Partasides Constantine with Redfern Alan and Hunter Martin, Redfern and Hunter on International Arbitration, Fifth edition, Student Version, Oxford University Press, 2009.

Clay Thomas, Larbitre, Dalloz, 2001.

Daele Karel, Challenge and Disqualification of Arbitrators in International Arbitration, Kluwer Law International BV, The Netherlands, 2012.

David René, Larbitrage dans le commerce international, Economica, Paris, 1982.

De Boisséson Mathieu, Le droit français de l'arbitrage interne et international, GLN Joly, 1990.

Deskoski Toni, Megunarodno arbitražno pravo, Skopje, 2016.

Fry Jason, Greenberg Simon, Mazza Francesca, The Secretariat's Guide to ICC Arbitration, International Chamber of Commerce ICC, Paris, 2012.

Gaillard Emmanuel, Savage John (editors), Fouchard Gaillard Goldman On International Commercial Arbitration, Kluwer Law International, The Hague, 1999.

Gavalda Christian, De Leyssac Lucas, Larbitrage, Dalloz, Paris, 1993.

Hascher Dominique, "Independence and Impartiality of Arbitrators: 3 Issues", American University International Law Review 27, No. 4, 2012.

Jarrosson Charles, “L'arbitrage et la Convention européenne des droits de l'homme”, Revue de l'arbitrage, 1989.

Jarrosson Charles, La notion d'arbitrage, LGDJ, Paris, 1987.

Jolidon Pierre, Commentaire du Concordat suisse sur l'arbitrage, Berne, 1984.

Kaufmann-Kohler Gabrielle, Rigozzi Antonio, Arbitrage international: Droit et practique à la lumière de la LDIP, 2nd ed. 2010.

Knežević Gašo, Pavić Vladimir, Arbitraža i ADR, Beograd, 2010.

Lalive Pierre, Poudret Jean François, Reymond Claude, Le droit de l'arbitrage interne et international en Suisse, Lausanne, 1989.

Lew Julian D.M., Mistelis Loukas, Kröll Stefan, Comparative International Commercial Arbitration, Kluwer Law International, the Hague, 2003.

Mustill Michael J., Boyd Stewart C., Commercial Arbitration, $2^{\text {nd }}$ edition, London and Edinburgh, Butterwords, 1989.

Perović Jelena, “Efikasnost arbitražnog postupka”, Pravo i privreda, No. 4-6/2017.

Perović Jelena, “Jezik arbitražnog postupka u međunarodnoj trgovinskoj arbitraži”, Liber amicorum Gašo Knežević, Pravni fakultet Univerziteta, Centar za izdavaštvo i informisanje, Udruženje za arbitražno pravo, Beograd, 2016. 
Perović Jelena, "Konstituisanje arbitražnog veća u međunarodnoj trgovinskoj arbitraži”, Pravni život, No. 11/2016, Beograd, 2016.

Perović Jelena, “Sumnja u nezavisnost ili nepristrasnost arbitra kao osnov zahteva za njegovo izuzeće”, Pravni život No. 11/2017, Beograd, 2017.

Perović Jelena, Đorđević Milena, "Resolution of Commercial Disputes Through Arbitration as a Contribution to Improvement of Business Environment in Serbia", Ekonomika preduzeća, March-April 2013, Beograd, 2013.

Perović Jelena, Standardne klauzule u međunarodnim privrednim ugovorima, Beograd, 2012.

Perović Jelena, Ugovor o međunarodnoj trgovinskoj arbitraži, Beograd, 2002.

Perović Slobodan, Obligaciono pravo, Beograd, 1990.

Poudret Jean François, Besson Sébastien, Comparative Law of International Arbitration, $2^{\text {nd }}$ edition, London, 2007.

Russell on the Law of Arbitration, Walton and Vitoria Eds., $20^{\text {th }}$ ed., Stevens and Sons, 1982.

Smith Murray L., "Contractual Obligations Owed by and to Arbitrators: Model Terms of Appointment”, Arbitration International, Vol. 8, no. 1, LCIA, 1992.

Stanivuković Maja, Međunarodna arbitraža, Beograd, 2013.

The Arbitral Process and the Independence of Arbitrators, ICC Publication, No. 472, Paris 1992.

The Arbitrator's Liability Report from the Club des Juristes, Ad hoc Commitee, June 2017, Paris, 2017.

Verbist Herman, Schäfer Erik, Imhoos Christophe, ICC Arbitration in Practice, Second Revised Edition, Kluwer Law International, The Netherlands, 2016.

Article history

Received: 14.10.2019.

Accepted: 20.10.2019. 